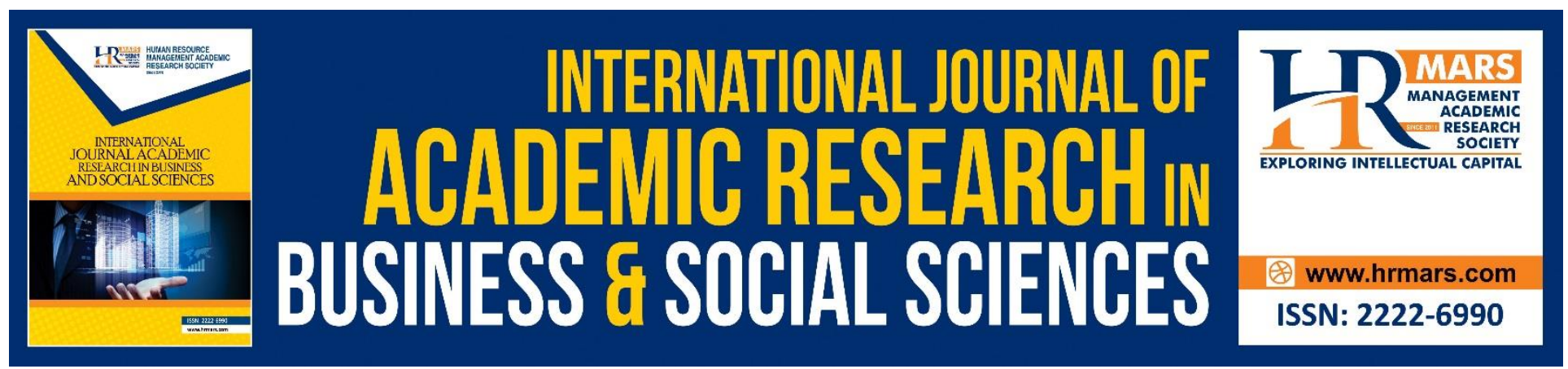

\title{
Prevention of Addiction Based on Islamic Ways
}

\author{
Muhammad, N.H.N, Omar, S.H.S., Thoalim, A.S., Mohamad, N.
}

To Link this Article: http://dx.doi.org/10.6007/IJARBSS/v9-i2/5621

DOI: $\quad 10.6007 /$ IJARBSS/v9-i2/5621

Received: 19 Jan 2019, Revised: 15 Feb 2019, Accepted: 25 Feb 2019

Published Online: 09 March 2019

In-Text Citation: (Muhammad, Omar, Thoalim, \& Mohamad, 2019)

To Cite this Article: Muhammad, N. H. N., Omar, S. H. S., Thoalim, A. S., \& Mohamad, N. (2019). Prevention of Addiction Based on Islamic Ways. International Journal of Academic Research in Business and Social Sciences, 9(2), 865-875.

\section{Copyright: (C) 2019 The Author(s)}

Published by Human Resource Management Academic Research Society (www.hrmars.com)

This article is published under the Creative Commons Attribution (CC BY 4.0) license. Anyone may reproduce, distribute, translate and create derivative works of this article (for both commercial and non-commercial purposes), subject to full attribution to the original publication and authors. The full terms of this license may be seen

at: http://creativecommons.org/licences/by/4.0/legalcode

\section{Vol. 9, No. 2, 2019, Pg. 865 - 875}

Full Terms \& Conditions of access and use can be found at http://hrmars.com/index.php/pages/detail/publication-ethics 


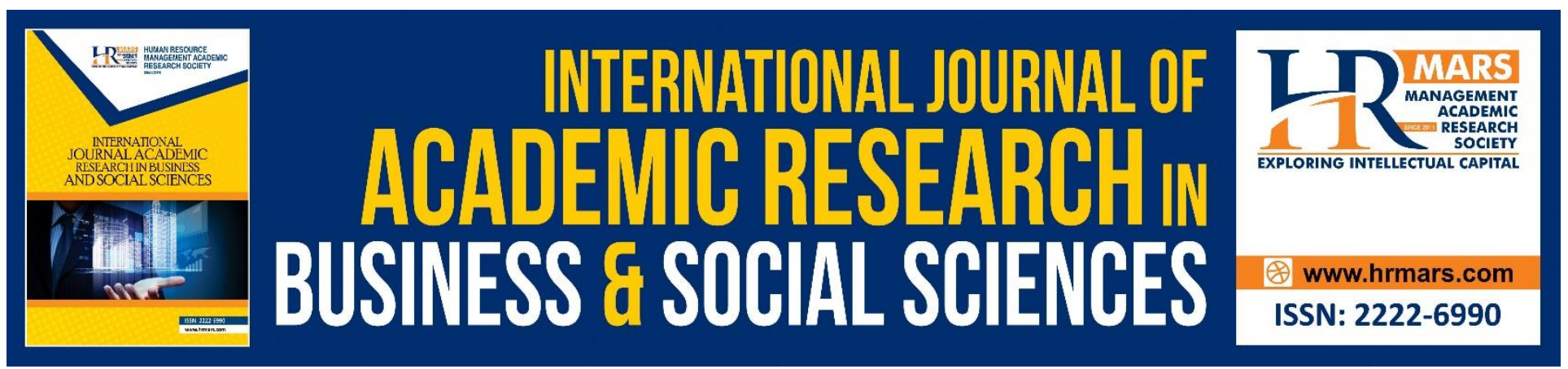

\title{
Prevention of Addiction Based on Islamic Ways
}

\author{
Muhammad, N.H.N. ${ }^{1,4}$, Omar, S.H.S. ${ }^{1,2,4}$, Thoalim, A.S. ${ }^{1,4}$, \\ Mohamad, N. . $^{3,4,5}$ \\ ${ }^{1}$ Faculty Contemporary Islam, ${ }^{2}$ Institute of Product Research and Islamic Civilization (INSPIRE), \\ ${ }^{3}$ Centre for Community Development \& Quality of Life (iCODE), \\ ${ }^{4}$ Centre for Research in Addiction (CENTRENA) University Sultan Zainal Abidin, Kampus Gong Badak, \\ 21030 Kuala Terengganu Malaysia ${ }^{5}$ Faculty of Medicine, University Sultan Zainal Abidin, 20400, \\ Kuala Terengganu, Terengganu, Malaysia
}

\begin{abstract}
Islam is a religion which emphasizes purity of civilized human life. Purification is part of the faith that works to produce individuals who abide by Islamic law. The problem of drug abuse is view seriously in recent years around the world. Therefore, prevention is very important to prove that Islam can solve various social problems. This article discusses the causes of addiction and how to address the treatment of drug issues with a view to a religious perspective as an alternative that can enhance the spiritual heir to generation. These elements serve as a fort very personality who can prevent the person from being involved with addiction problems of social ills today. This study is a qualitative analysis using design documents and library with research on prevention and treatment of addiction. The review found some way of treatment for those who are involved with social problems in drug addiction. Therefore, sympathize with and reach out to the Islamic guidance and treatment can help to solve the problem of addiction.
\end{abstract}

Keywords: Causes of Addiction, Treatment of Islam, Drug Addiction

\section{INTRODUCTION}

The challenge facing the world today is globalization on the development of the nation. Nowadays, the average involved in social problems as a result of technological advances and changes in various aspects of life. Among them is the problem of drug addiction. This problem has been dealt with since the start of the 70s again. Up to now the drug problem is still not showing a positive change (Razak, 2004).

The National Fatwa Council issued a fatwa that drug abuse is forbidden in Islam declared on 15 April 1982. This fatwa issued by the Fatwa Committee of the 3rd National Council for Islamic Religious Affairs. The drug problem is very closely linked to emotional turmoil and uncertainty feelings. People suffering from the emotional development of complex and need religious guidance in handling it. 
Emotion is a reaction to stimuli and has a driving force to the treatment. It is a bodily and psychological response that affects the daily lives of individuals and society (Murry, 1964).

If not given adequate attention to the problem of drug addiction will risk doing aggressive behavior due to expression exterior that cannot fit in, are not accepted in the social and family norms, and the reaction pressure inside the individual self (Hussin, 2012). Therefore, people should take the initiative to help reshape the personality of those who have problems with drug addiction based on the Islamic model.

Drug problem is caused by failing to appreciate the religious guide in life. It makes people fail to distinguish between right and wrong. There are various methods involved with drug rehabilitation among psycho-spiritual therapy that focuses on methods of prayer, study, chanting and Islamic studies classes. In addition, as religious approach repentance, remembrance, "qiyamullail", fasting, prayer and care for manners in treating individuals who are involved in drug abuse (Nazar, 2005; Yusof, 2008).

Dara et.al (2013) in his study found the treatment of drug addicts through methods that focus on the aspects of inner peace through mysticism capable of self-cleaning and can enlighten an individual about the original purpose of their creation as the Caliph of Allah and thus foster a sense of high responsibility in themselves.

Therefore, for the treatment of heart disease, some of the scholars decided there were five bidders, namely reading al-Qur'an, empty stomach (fasting), "qiyamullail", beg forgiveness and mercy in the morning and attended the righteous (Azizan, 2012). The religious approach help address social problems in a society guided by Islamic way of treatment.

The differences this study with previous study is this study focus more on purify their hearth, spirituality or "ruh al-nafs" to prevention drug addiction in society in continuously. The previous study just focus on spiritual ('amal). So that's the gap reasons between this study and past. This study held observation participant and hopefully will help society to recover from addiction. From this study, the result showed drug addiction can solved by practice Islam and spirituality.

\section{CAUSE OF ADDICTION}

There are several causes of addiction is mentioned as a reasonable basis for the occurrence of this drug problem. Among the most notable is the attitude of parents, religious education is shallow, the role of peers, broken heart and act according to their desires.

\section{ATTITUDE OF PARENTS}

Some parents do not really care growing children. Some even privatize the responsibility of the education of children from third parties such as the salary, nursery, neighbors, and friend (Yusoff, 2008).

In the pursuit of life and career, the parents are now more tolerant to the manager to hand over the responsibility of raising children to others. The effect of that has led to a sense of love and respect for parent decreases and eventually eroded. When growing up, advice and counsel from parents will always be denied by their own children (Yusoff, 2008). 
As resorting to tame the kids, then the parents replace the affection with money and material. There are also parents who replaced it with freedom and screwing up their kids involved with drug addiction (Yusoff, 2008).

\section{LACK OF RELIGIOUS EDUCATION}

Got a shallow religiosity also help the growth of social problems. Unfortunately for Muslims if only know about his religion in fragments only. There are those who understand that religion in matters related to the worship of prayer, fasting, and the like perpetually public only. They do not go into their religion as something that stems from faith and all aspects of religious life deviations from reward and punishment semicolon. They do not understand religious laws that will affect their behavior in mixing between men and women (Yusoff, 2008).

\section{PEER INFLUENCE}

This element is often associated with drug abuse that occurs among adults now. Usually they do not get the attention of the house will find a peer that can satisfy the ego and requirements. They will join them to form a group of young and usually it consists of the same kind among them. Those involved were from families whose parents work and ignore the responsibilities towards children (Ahmad, 2005).

For individuals who find happiness outside the house in the beginning they both attended the "walk stock" supposedly finds peace with musical accompaniment. Then they tried the drug in order to maintain the peace. When it becomes increasingly addiction, they are no longer able to recognize the good and bad. What is important at the time was how their desires to be fulfilled (Ahmad, 2005).

\section{DIRTY AND BROKEN LIVER}

Prophet Muhammad said that in the body you have a blood clot, if he is good then let all the human body if he is a bad man then rose to be bad anyway, know he is happy (Narrated by Bukhari and Muslim).

Al Ghazali Model in Sara (1997) and Yatimah (2005) explain the liver or humiliate is an important part of a man who still work since the life of the world to the Hereafter. Liver is function or "Qalbu" not stopped or broken by the arrival of death. But the heart will continue to play a role in nature Hiking. Be clear and clean will take us on a comfortable living and remain forever in God. Liver were dirty, smelly and full of disease will lead people to do bad things.

In this context, individuals who have a liver that is dirty, damaged, hardened and finally closed his liver to receive instructions and guidance of Allah, otherwise likes to condemned properties involved with addiction symptoms, socially independent and adultery. This is clear from Al Ghazali (1977) in Tunku Sara (1997), the liver has a huge effect on humans as it is able to attract people to salvation or perdition world and the hereafter. This means that people who act according to the desires that could destroy the human consequences of his actions that harm it. And for them is a great punishment (Surah Al Baqarah, verse 7). They are the ones whose hearts, hearing and sight are sealed by Allah and they are the ones who default (Surah Nahl, Verse 108). 


\section{ACTING BY DESIRES}

Al Ghazali (1977), Jaafar (1996) and Jawzi (2000) states that every human being has desires. Passions act according to conscience. The devil led him to meet the desires and demands of the beauty and goodness of its properties are despicable. Here, they feel like the true and right path, but know that the devil had deceived them without realizing it.

Allah says; meaning: He who turns away from the remembrance of the Most Beneficent (Allah), we appoint for him a Satan (misleading), then the devil that is the friend that always accompanies it. And indeed, the devils really hinder them from the truth and they think that they are guided. (Surah AzZukhruf, Ayat 36-37)

Man who act according to the whims able to humble dignity as a caliph to fill it with a variety of ways and act like a voracious sexual indulgences, addiction and so on. Subject only livelihood and devote Him to the guidance of passion. Add a sad, they do not care about the laws of clean and unclean that God Almighty, even meet their desires are more important things. In this context, mystics explain that the human passions which tend to indecency and evil (Azizan, 2016).

\section{SUGGESTION TREATMENT OF CONVENTIONAL}

The disease of addiction is a concern of many parties when it is increasing every year. When we talk about addiction often it is associated with drug addiction over the years to be taken seriously by the government. The fact is that people today are not only dealing with drug addiction and even various forms of addiction that invites serious problems if left unchecked.

Treatment and rehabilitation of drug addiction need to combine the best of conventional and religious approach. Drug addiction is not able to be fully restored without an appreciation of the science of religion. He explained that the approach to spirituality and religion, regardless of religion and belief is essential to restore the overall addiction for a long time. Ahmad Zahid said the effort to combat drug abuse in this country should not be held entirely to the government but also to involve themselves, parents and other agencies.

Dr. Muhammad Muhsin, who is also the Chairman of the Organizing Committee of the ISAM said, drugs or heroin by taking methadone and opiates, noticeable effects that we can see since taking methadone to treat drug addiction heroin, which was 70 per cent HIV among drug users, is now down to 25 per cent, this includes the development of scientifically how the role of the brain during the applicable billing to help provide effective treatment to addicts. Transformation of approaches to deal with drug addiction as previously involved only in terms of social and legal, now further enhanced through medical treatment.

Dr. Speransky Sargei found new methods to solve the problem of addiction, which is a whipping repeatedly involved patient with drug addiction. It seems that this method is rather violent, but that the most effective methods according to the lead researcher. And then, with lashes on the back, a hormone released by the body that acts as an antibody against the effects of alcoholism. Endorphins are a natural chemical found in the human body easily secreted out when whipping back time after time. These chemicals are known as chemicals cheerful or happy chemicals that act invigorate patient from anxiety. Chemicals also get rid of the addiction. Drug addiction is a psychological disease compared with physical problems and with strokes of an effective treatment method for both cases. 


\section{SUGGESTION TREATMENT OF ISLAM}

Al-Qur'an is a way for someone recuperating from despicable nature and replaces it with an admirable trait. There are several methods of recovery prescribed by the Qur'an of which the first is a method of prevention and control. Secondly is medication and treatment. While the third is the guidance and coaching of an intensive recovery effort to avoid sins and build a state of spiritual and psychological better.

Analyses of documents and libraries have found the best educational approach to religion is through the Qur'an and al-Sunnah in the treatment of those addicted. It also makes the system implemented has the effect of spirituality in their lives. It can help address the social problems of the present time based on the Qur'an and religion.

\section{PRAYERS}

According to Imam al-Shafi'i, prayer is a way of the heart (conscience) to turn to God so as to generate s.w.t fear of God s.w.t and appeared in the heart of the glory of God s.w.t (Hasan, 2013). Prayer is an important matter to be taken seriously by all mankind. It is as a peg in a person who will determine both bad manners and way of life in this world and the hereafter. Islam educates people with physically and mentally able to make people worship as disciplined because it has its own rules and regulations (Norzulaili \& Zohdi, 2005). Command is enshrined in the Holy Quran and the sayings of Prophet S.A.W.

Word of God, which means: to establish regular Prayer, give regular Charity, and hold fast to Allah! $\mathrm{He}$ is your Protector. Then (God Such) He is the Best to protect and the Best to help. (Surah Al-Hajj 22:78).

Imam Ibn Kathir in explaining this verse states that the purpose of that paragraph that receive a huge favor by grateful and what God S.W.T give rights to do what is required of you and leave what is forbidden (Kathir, 2007). It also explicitly mentioned in the hadith of the Prophet of Islam is built upon five of whom were praying.

Word of the Prophet, which means: Of 'Ikrimah bin Khalid Ibn Umar said: The Messenger of Allah said: "Islam is built on five (substrate); the testimony there is no god except Allah and that Muhammad is the Messenger of Allah, establish regular prayers, practice regular charity, pilgrimage and fasting Ramadan ". (Narrated by Bukhari, Book of Faith, no. 7).

Congregational or compulsory prayers will shape human hearts with love, it also creates a discipline in a person, discloses the glory of Islam and the basis of human know one another. Instead of praying pilgrims will train someone as a leader and the people, it is the basic model to the formation of one's personal. People who do not perform the prayer then there is no good moral structure of society, it is the principle of the prayer life balance. Prayer will be implemented awareness and influence the actions and behavior. (Hasan, 2013).

\section{LEARN PRACTICAL PRAYER}

The purpose of the creation of man on this earth is to worship God S.W.T But worship that should be implemented to the science of how it should be implemented. Worship without knowledge is useless because it is feared not meet the requirements of the Shariah. The importance of clear when the first verse was revealed to the Prophet was concerned to read, and it is the basis of the instruction and 
study. The importance of knowledge can be attributed to human reason, cultivation in the Quran focuses on the mind, body and spirit. Quran educate people with three main aspects to produce moral perfection (Norzulaili \& Zohdi, 2005).

Word of God, which means: read (O Muhammad) with the name of your Lord who created (all that exists) (Surah 96: 1).

Clear reading instruction as an intermediary to get knowledge. In fact, there is knowledge that must be learned the science necessarily "Fard Ain". It is a basic science that needs to be there in person. Examples of "Tawhid" (Oneness of God), the method of reading the Quran, the method of prayer, fasting and all the laws that have been established by God s.w.t in the implementation of Sharia. Science as a foundation for an entry into paradise and live accordingly. Practice sessions with science will help a person closer to God s.w.t and simplify the way to heaven. It is called by the Prophet as an encouragement for human studies.

Word of the Prophet, Meaning: From Abu Hurairah, he said, "The Prophet said:" It is not a man who walked on the path to seek knowledge but Allah will make easy for him the road to Paradise. He who is slow legalization would not give him the benefit of his lineage. "(Sunan Abi Dawood, Book of Knowledge, no 3158).

In a hadith clearly shows that the pursuit of knowledge is a way to simplify the way a person has a paradise. Implementation of prayer must be perfect as the requirements of Shariah (Azizan, 2016)

\section{READ QURAN "TILAWAH", "TAHSIN" AND "TADABBUR QURAN"}

Al-Quran is the word of God s.w.t revealed to the Prophet Muhammad did and read it counted as worship. The position of the Quran is so high and people must put it in its rightful place, namely memorizing, appreciate, read and "tadabbur" any means (Kamel, 2006). However, it should be understood that the recitation of the Quran is considered as worship if it is read properly and correctly according to the articulation and the rules set by Allah. Word of God, which means: or add (a little), and chant the Qur'an with "measure". (Surah Muzammil 73: 4).

The purpose of reading is "tartil" were read the Quran slowly as it will help in understanding and gazed at it. (Ibn Kathir, 2007). Read the Quran with proper rules of recitation and pronunciation of proper articulation is necessary even if it is read by one of his readers will bear sin? The Qur'an will be intercessors for the people in reaching heaven God S.W.T. It is clearly mentioned in the hadith of the Prophet S.A.W.

Word of the Prophet, it means: 'Abdullah bin' Amr, he said; He said: "It was said to the people who read the Qur'an:" Read it and went up, and consult with "tartil" (do not hurry), as you read pornography in the world, indeed, your place is at the end of the paragraph that you read. "(Sunan Abi Dawood, Prayer Book, No. 1252).

Hadith is mentioned that by reading the Qur'an with the best methods, the reason a person enters heaven God S.W.T Features which proves that the Qur'an is always appreciated reading the Quran, read pornography, taught the Quran to others and understand the contents of the Quran (Kamel, 2006).

All men are required to return to the religion of nature, the best education is based on the Qur'an recitations and teach the Quran "tahsin". The next is "tadabbur" verses of the Qur'an to get better. "Tadabbur" understanding of the Qur'an is an important process in respect of religion implying, The 
INTERNATIONAL JOURNAL OF ACADEMIC RESEARCH IN BUSINESS AND SOCIAL SCIENCES

Vol. 9, No. 2, Feb, 2019, E-ISSN: 2222-6990 C 2019 HRMARS

Quran describes many stories that can give "ibrah" to humans, it can form the soul and human feelings and is an effective way of preaching (Norzulaili \& Zohdi, 2005).

\section{"QIAMULLAIL"}

"Qiamullail" is God gift to His servants. It's a special time to pray to God. People will feel the blessings pray to God. This point in time because there are no disturbances such as daytime bustle and religious situation became calmer. "Qiamullail" implemented to provide a space for people to repent of past sins and purify self with repentance to Allah S.W.T. Word of God, which means: Surely the rising by night is most potent for governing (the soul), and more certain.

According to Umar al-Khattab, Ibn Abbas and Ibn Zubair whole evening was to get up. It is amplified by "Mujahid" and others. (Ibn Kathir, 2007). "Qiamullail" will strengthen the liver, oral and more humility 'in prayer, time and space are likely to make people complain all the problems and worries of life.

Word of the Prophet, it means: The Prophet said: "Whoever wakes up at night and read" There is no god except Allah alone, no partner to Him. It is He Who has dominion and to Him belongs praise: and He has power over all a. Praise be to Allah and Glory be to Allah and there is no god except Allah and Allah is Great and has no power and effort but with him) was followed by reading "God forgive me" or prayer, it will be granted him. If he ablution and pray his prayers will be accepted "(Sahih Bukhari, Book on Friday, no 108).

"Qiamullail" give way to a man in self-reflection on the sins that have been committed. Accordingly, the reflection is also among one of the other ways in dealing with social problems. Al-Muhasibi believes reflect on life can be done in two circumstances, namely, reflect on the deeds to come and reflect on the deeds of the past (al-Muhasibi, 1990, 45). Introspection in the works that will come is staring and observing the behavior of the soul in a way that does not control the human soul in a hurry in taking any action and behavior that deviates. While reflect on the deeds of the past are calculated by taking the life lessons and the lessons learned from the actions and behaviors that have been done before it (Azizan, 2016).

Thus it is clear that excess "Qiamullail" given by God to His servants. It's not just the physical punishment of those addicted, but the application of spiritual values in them to make their personality and character remained intact in the community in the future.

\section{FAST}

Islam teaches mankind to be submissive and obedient to any religious teachings. Obligations in worship supported by voluntary deeds another. It is a way to increase the reward goodness of human beings in the hereafter. It is clearly mentioned in the Quran and sayings of Prophet Muhammad.

Allah says, which means: and men who fast and the women who fast, and men who guard their chastity and the women who guard their chastity and men who remember Allah much as well as those women who remember Allah much: Allah has prepared for them forgiveness and a great reward (Surah al-Ahzab 33:35).

Among the circumcised in a religious fasting is fasting six days in "Shawwal", "Muharram", fasting days and 15 white which is 13.14 per month Muslim fasting Arafat on the 9th day of Dhu al-Hijjah, 
INTERNATIONAL JOURNAL OF ACADEMIC RESEARCH IN BUSINESS AND SOCIAL SCIENCES

Vol. 9, No. 2, Feb, 2019, E-ISSN: $2222-6990$ ๑ 2019 HRMARS

the 10th of "Muharram" fasting the day of "Ashura", and fasting Monday and Thursday fasting Dawud (Azizan, 2016).

Word of the Prophet, which means: Hafsah said; "Four things never abandoned by the Prophet was fasting 'Ashura, the tenth day of fasting, fasting three days each month and two "rak'ahs" before the dawn" (Sunan Nasa'i, Book of Fasting, no 2373).

Fasting is the best course of treatment and education, it teaches people to be patient and keep your self-respect. This process is seen to be helping the addicted to drugs that are no longer involved with other social problems (Azizan, 2016).

\section{ZIKR}

"Zikr" or remembrance is one of the medium in the draw closer to God S.W.T Remembrance makes the human heart calm and able to live wisely. "Zikr" of Allah s.w.t effect from remembrance of Allah mentioned in the Quran and hadith (Azizan, 2016).

Word of God, which means: "(They are) those who believe and their hearts to the remembrance of Allah". Know with "Allah", the hearts are satisfied (Al-Ra'd 13:28).

Life will not bring any meaning if the heart is not quiet and restless even have resources in abundance. To acquire the peace of God should remember s.w.t man, even the quiet heart is referred to as a rich man in the sight of Allah S.W.T Word of the Prophet, meaning Abu Huraira Prophet did say: "Is not it because the number of property wealth, but that wealth is like a heart" (Sahih Bukari, Kitab al-Riqaq, no 5965).

\section{RECOMMENDED PRAYER}

Prayers especially "Duha" have its own specialty. It is enshrined in the Quran that Allah S.W.T swears by mid-morning. God s.w.t only will swear to being special and beneficial to humanity and goodness. God word means: By mid-morning (Surah al-Duha 93: 1).

This verse shows the power of God s.w.t arguments when making mid-morning and evening to humans. (Ibn Kathir, 2007). So, both of these as beneficial to humans in their lives. In the hadith of the Prophet was also explained "Duha" of good practices undertaken by the Prophet S.A.W. to draw closer to God s.w.t and ask for help and help from God S.W.T (Azizan, 2016).

Word of the Prophet, it means: From Anas bin Malik said, in a way I saw the Prophet doing "Duha" of eight cycles, when it was finished he said, I pray between hope and fear, I ask in Rab three things, He granted two demands and rejects all three, I ask that people not afflicted by disaster, and not ruled over them, and God grant it, then I ask to not be divisions among my people, and God rejected it (Musnad Ahmad, Musnad Chapter Anas b. Malik, no 12129).

"Duha" required for forming personal character and the honorable in society. It is also one of the prevention and rehabilitation with discipline in implementing the prayers. The exercise of worship can help overcome the problem of drugs in society. Worship will form a sense of ungodliness and interaction between reason and act before doing an act, it cannot prevent those addicted again involved with a drug problem (Azizan, 2016).

The study found the document and the library of remembrance is an important application of those executed on drug addiction in order to prevent and deter them from engaging with the symptom of addiction (Azizan, 2016). 


\section{PREVENT AND PRESERVE THE HEART}

Darussalam (1997) describes the human heart is aware of the most important elements in life that will work until the end of time. Therefore, we must care for and maintain it properly to avoid damaged and filled with diseases that can give misery to man. Be clean and clear is the heart always remember to Allah, at any time to communicate with God, so it is always in counseling and guidance. Eyes, heart and the human body is always guided by the heart to always see, hear and receive advice and guidance from God with an open heart.

Some ways to maintain and care for your heart is so clean:

1. Always remember God wherever we are.

2. Always praise your greatness.

3. Take perfect if you have a claim lust.

4. Immediately ask for forgiveness for the mistakes and sins of the past.

5. Always chanting to purify.

6. Always seeking refuge from the temptations of the devil and the cunning of the world's neglect.

7. Always ask for God's guidance in life.

8. Always read and listen to verses from the Qur'an and "tadabbur" every day.

9. Practice caution with the properties to be human fear "mahmudah" like resignation, patient, sincere, honest, trustworthy, pleased, love, anger, abstinence, and so on.

10. Clean the heart of nature "mazmumah" like arrogant, boastful about, seen, envy, resentment, treacherous, greedy, and so indulge.

\section{CONCLUSION}

The heart is the source of all works and human qualities which disgraceful. Adjacent to the act of addiction, immorality and adultery is a man who has a heart that is dirty, damaged and die. Commandment otherwise tend to be ignored by the conscience of persuasion and deception of Satan. Thus, with the spread of the issue and the problem of addiction, promiscuity and sex among the youth of today, it's time for a preventive measure was taken based on how Islamic treatment of a sustainable approach or process recovery and prevention to address the social problems of addiction. Method according to Qur'an and Sunnah that are used are also capable of injecting spirit in those billing to turn toward life based on Islam than their previous lives. So, at the core of the spiritual is aspect in building their identity in order to face the challenges of an increasingly sophisticated world. However, the support and the important role of parents, families, local communities and those responsible for those addicted is very important to help them always in pristine condition and can prevent them from getting stuck again. Preventive measures are necessary, especially in challenging new millennium. Hopefully heir Islamic state does not continue to drift and become coatings Country that can develop the country.

The role of this study to contribute of the society solve the drug addiction continuously with Islamic ways. It is because in Islam have many beautiful ways and guidance to follow and practice to prevent and avoid drug addiction in society. 
INTERNATIONAL JOURNAL OF ACADEMIC RESEARCH IN BUSINESS AND SOCIAL SCIENCES

Vol. 9, No. 2, Feb, 2019, E-ISSN: 2222-6990 C 2019 HRMARS

\section{Acknowledgement}

This project is supported by NRGS/2014 grant number RR057-1 from Malaysia Ministry of Higher Education.

\section{Corresponding Author}

Syed Lutfi Syed Omar, Institut Penyelidikan Produk dan Ketamadunan Islam (INSPIRE), Email: Sylutfi.gmail.com.

\section{References}

Ibrahim, A. A. M. I. B. (2007). Sahih Bukhari. Dar al-Hadith: Kaherah. Retrived from http://book.google.com.

Ali, A. A. A. N. (2005). Sunan al-Nasa'i. Dar al-Kutub al-Ilmiyyah: Riyard. Retrived from http://book.google.com.

Sulaiman, A. D. (2006). Sunan Abi Daud. Dar al-Hadith: Kaherah. Retrived from http://book.google.com.

Hanbal, A. (2008). Al-Musnad. Muassasah Al-Risalah: Beirut. Retrived from http://book.google.com. Azizan, N. I. (2016). Pendekatan Al-Quran Dalam Menangani Masalah Sosial Di Pusat Perlindungan Mais Menurut Perspektif Pelatih. International Conference Aqidah, Dakwah and Syariah 2016 (Irsyad 2016).

Mohamed, A. K. (2006). Penghayatan al-Quran dalam kehidupan dalam "Isu semasa pengajian Quran dan Sunnah. Fakulti Pengajian al-Quran USIM: Nilai.

Ali, D. A. H. M. A P. (2013). Drug addict treatment and rehabilitation programmed at Pondok Inabah Kuala Terengganu, Terengganu, Malaysia (1998-2011). British Journal of Social Sciences. Vol. 1. No. 5. HIm. 37-46. ISSN: 2326-4209.

Ali, H. (2013). Hal-hal yang membatalkan solat anda. Al-Hidayah House of Publisher Sdn Bhd: Selangor.

Kathir, I. (2007) Shahih Tafsir Ibnu Kathir. Maktabah Dar al-Salam: Riyadh.

Mohamed, M. N. (2005). Program pemulihan luar institusi untuk penagih dadah. Sintok: Universiti Utara Malaysia.

Merriem, S.B. (1998). Qualitative Research and Case Study Applications in Education. Ed. 2. San Fransisco: Jossey-Bass.

Ghazali, N. (2005) Metod al-Quran Dalam Membina Akhlak dan Peribadi dalam "Isu semasa pengajian Quran dan Sunnah siri 2. MES enterprise Sdn Bhd : Kuala Lumpur.

Ahmad, R. (2005) Punca, Kesan Dan Langkah Untuk Menangani Tingkah Laku Seksual Pelajar Mengikut Pendekatan Kaunseling Islam. 